\title{
Mesleki Davranış Anketinin Türkçe Geçerlilik ve Güvenilirliği
}

\author{
Reliability and Validity of Professional Behavior Questionnaire \\ Sinem KARS ${ }^{1}$, Gökçen AKYÜREK ${ }^{2}$, Gonca BUMIN ${ }^{3}$ \\ ${ }_{1}$ Uzm. Erg., Hacettepe Üniversitesi, Sağlık Bilimleri Fakültesi, Ergoterapi Bölümü, Ankara, Türkiye \\ ${ }^{2}$ Doç. Dr., Hacettepe Üniversitesi, Sağlık Bilimleri Fakültesi, Ergoterapi Bölümü, Ankara, Türkiye \\ ${ }^{3}$ Prof. Dr., Hacettepe Üniversitesi, Sağlık Bilimleri Fakültesi, Ergoterapi Bölümü, Ankara, Türkiye
}

\section{ÖZ}

Amaç: Bu çalışmanın amacı ergoterapi öğrencileri için “Mesleki Davranış Anketi”nin Türkçeye uyarlama çalışması yapılarak ölçeğin psikometrik özelliklerinin incelenmesi amaçlanmıştır. Gereç ve Yöntem: Orijinal anket üç faktör ve 28 maddeden oluşan beşli likert tipinde bir ölçme aracıdır. Çalışmaya ergoterapi bölümünde öğrenim gören gönüllü 151 öğrenci dahil edildi. Araştırmada ölçeğin dilsel eşdeğerliği incelendikten sonra geçerlik ve güvenirlik analizleri yapıldı. Ölçeğin geçerlik ve güvenirlik analizleri için SPSS AMOS 23.0 paket programı kullanıldı. Ölçeğin yapı geçerliliği için doğrulayıcı faktör analizi yapıldı. Ölçeğin güvenirlik çalışması iç tutarlııı katsayısı (Cronbach Alfa) ve test tekrar test yöntemi kullanılarak incelendi. Sonuçlar: Açıklayıcı faktör analizinde ölçeğin, özgün formuna benzer olmayan bir faktör yapısına sahip olduğu görülmüştür. Sorunlu olan beş maddenin modelde yer almadığı yedi faktörlü yapının yapı geçerliliği doğrulayıcı faktör analizi kullanılarak test edilmiş ve söz edilen modelin yapı geçerliliği model uyum ölçütleri kullanılarak ortaya konulmuştur. Ölçeğin Türkçe formunun Cronbach alfa katsayısı $=0,858$ olarak hesaplanmıştır. Tartışma: Türkiye'de yeni bir sağlık mesleği olan ergoterapistlerin mesleki davranışlarının mesleğin gelişimi açısından önemli olduğunu düşünmekteyiz. Bu nedenle ergoterapi öğrencilerinin lisans eğitimi sırasında mesleki davranışlarının incelenmesi için bir psikometrik araca intiyaç vardır; dolayısıyla bu çalışma aracılığıyla ergoterapi öğrencilerinin mesleki davranışlarının incelenmesi mümkün olacaktır.

Anahtar Kelimeler: Profesyonellik; Ergoterapi; Öğrenciler; Güvenilirlik ve Geçerlik

\section{ABSTRACT}

Purpose: To adapt the Professional Behavior Questionnaire (PBQ) into Turkish culture by ensuring the structural validity and reliability of the scale in order to measure occupational therapy students. Material and Methods: The PBQ is consisted of 3 subscales and 28 items according to a Likert scale Quintet. The study group consisted of 151 occupational therapy students. The SPSS AMOS 23.0 package program was used to check the validity and reliability. Confirmatory factor analysis (CFA) was performed to examine the validity of the model of the Turkish form of the PBQ. The reliability of the scale was examined by using internal consistency coefficient (Cronbach alpha) and test-retest method. Results: In the exploratory factor analysis, the factor structure of PBQ-TR differed from the original form. The structural validity of the 7-factor model formed after excluding five problematic items was tested by confirmatory factor analysis and proven to meet the goodness of fit criteria. The Cronbach's alpha coefficient of the PBQ-TR was 0.858. Conclusion: Professional behavior of occupational therapists is important for the development of the profession. Therefore, there is a need for a psychometric tool to evaluate occupational behavior of students during their undergraduate education.

Keywords: Professionalism; Occupational Therapy; Students; Reliability and Validity 
Eğitim yoluyla edinilen yeterli bilgi ve beceriye sahip olan bireyler tarafından, yasal ve etik kurallar doğrultusunda topluma hizmet veren uğraşlar meslek olarak tanımlanabilmektedir (Güven, 2009). Bir uğraşın meslek olarak ifade edilebilmesi için, belirli özelliklere sahip olması gerekmektedir (Çelik, Ünal ve Saruhan, 2012). Bu özellikler; bireysel sorumluluğun olması, bilgi bütünü temelinde öğrenilmiş olması, kuramsal bilginin yeniden üretilebilir olması, eğitimsel bir disiplin doğrultusunda tekniklerin öğretilebilir olması, örgütlenmesinin çok iyi yapılmıs olması ve alturizm (özgecilik) yoluyla üyelerin birbirlerine yardım etmeye eğilimli ve toplum yararına çalışmaya istekli olmasıdır (Flexner, 2001).

İnsanlık var olduğu sürece varlığını devam ettirecek olan birtakım meslek grupları bulunmaktadır. Bu meslek gruplarından birisi olan sağlık profesyonelleri, insanların kaliteli bir yaşam sürdürmesinde önemli bir yere sahiptir. Bir sağlık profesyoneli olarak ergoterapistler, 26 Nisan 2011 tarih, 27916 sayılı Resmi Gazetede yayınlanan 6225 nolu kanunun 9. maddesi s bendinde "iş ve uğraşı terapisi alanında lisans eğitimi veren fakülte veya yüksekokullardan mezun, sağlıklı kişilerde mesleği ile ilgili ölçüm ve testleri yaparak, mesleği ile ilgili koruyucu ve geliştirici programları planlayan ve uygulayan; hasta kişiler için uzman tabibin teşhisine bağlı olarak bireylerin günlük yaşam, iş ve üretkenlik, boş zaman aktivitelerine katıımını artırmak, sağık durumlarını iyileştirmek, özürlülüğü önlemek ve çevreyi düzenleyerek katıımı artırmak için gerekli iş ve uğraşı terapisi yöntemlerini uygulayan sağılı meslek mensubu" olarak tanımlanmıştır (Bazı Kanun Ve Kanun Hükmünde Kararnamelerde Değişiklik Yapılmasına Dair Kanun, 2011).

Uygulamaya dayalı disiplinlerden birisi olan sağlık disiplininde eğitim programının teorik bilgi ve klinik deneyimden oluşması gerekmektedir. Bu klinik deneyim, öğrencilerin sadece teorik bilgi ve uygulamaları arasında bağlantı kurmalarına yardım etmez, aynı zamanda ergoterapi uygulamalarında gelişimi de sağlar (Sullivan ve Thiessen, 2015). Kriz yönetimi, problem çözme, etkili iletişim, karar verme gibi süreçlerin sağlık bakım hizmetlerinin verildiği kurumlarda önemli beceriler olduğu düşünüldüğünde, eğitim kurumlarının öğrencilere verdikleri eğitimsel süreçleri gözden geçirerek öğrencilerin bu yönlerini de geliştirebilecek öğretim stratejilerini kullanmaları neredeyse zorunluluktur (Brown, Williams ve Etherington, 2016). Hackenberg ve Toth-Cohen (2018) tarafından yapılan nitel bir çalışmada, ergoterapistlerin mesleki davranışları incelenmiş ve sekiz alt başlıkta toplanmıştır. Bu başıklar iletişim becerisi, inisiyatif kullanabilme, klinik muhakeme, sağduyulu olma, stresle başa çıkma becerisi, kişilerarası iletişim becerileri ve öğrenme isteğidir.

Ergoterapistlerin mesleki davranışlarını belirlemeye yönelik araştırmalar yapılmıştır; ancak bu çalışmalar nitel çalışmalardır. Yuen, Azuero, Lackey ve arkadaşları (2016) tarafından geliştirilen Mesleki Davranış Anketi ergoterapistlerin mesleki davranışlarını inceleyen ilk ölçektir ve mesleki davranışı mesleki davranışı öğrenme isteği, öğrenme becerisi ve kültürel yeterlilikten oluşan üç boyut olarak incelemiştir. Bu kapsamda bu araştırmanın amacı, Mesleki Davranış Anketi'nin Türk kültürüne uyarlanarak psikometrik özelliklerinin incelenmesidir.

\section{GEREÇ VE YÖNTEM}

\section{Araştırma Deseni}

Metodolojik araştırma desenine göre planlanan bu çalışmada, Mesleki Davranış Anketi çoğunlukla Google Formlar ve kısmen de basilı formlar vasıtasıyla katılımcılara zincirleme örnekleme yöntemi ile ulaştırılmıştır. Anket 2017-2020 güz ve bahar dönemlerinde ergoterapi bölümünde öğrenim gören son sınıf öğrencilerine uygulanmıştır. Çalışmaya 151 ergoterapi öğrencisi dahil edilmiş ve öğrencilerden aydınlatılış onam formu alınmıştır. Çalışma Helsinki Deklarasyonu ilkelerine uygun olarak yürütülmüştür. Çalışmaya katılan ergoterapi öğrencilerinin yaş ortalamaları 22,8 $\pm 2,22$ (min-maks: 20-36 yıl) olup, \%82,8'i ( $n=125)$ kIz öğrenciydi. Mesleki Davranış Anketi

Yuen ve arkadaşları (2016) tarafından geliştirilmiştir. Ölçek; yirmi sekiz madde ve öğrenme isteği, öğrenme becerisi ve kültürel yeterlilik olmak üzere üç alt ölçekten oluşmaktadır. Öğrenme isteği alt ölçeğinin 5 ve 6 . maddeler; öğrenme becerisi alt ölçeğinin 13, 15, 16 ve 17. maddeler; kültürel yeterlilik alt ölçeğinin ise 24,25 ve 26 . maddeler oluşturmaktadır. Bu dokuz madde dışında yer alan on dokuz madde herhangi bir alt ölçekte yer almamaktadır. Ölçekte yer alan sorular ergoterapi öğrencisinin görevlerine, kendisi ile anlaşmasına ve diğerleri ile anlaşmasına yöneliktir. Ölçekte puanı ters kodlanan madde bulunmamakta olup, hiçbir zaman (1), nadiren (2), ara sıra (3), sıklıkla (4) ve her zaman (5) olacak şekilde beşli likert bir ölçektir. Ölçekten alınan yüksek puan yüksek mesleki davranışı yansıtmaktadır. Ölçeğin orijinal yapısına ait açıklayıcı ve doğrulayıcı faktör analizine ait sonuçlar Tablo 1'de gösterilmiştir. Ölçeğin orijinalinin Cronbach alfa iç tutarlık katsayısı 0,79 'dur. 
Tablo 1. Mesleki Davranış Anketi'nin orijinal yapısına ait analiz sonuçları

\begin{tabular}{|c|c|c|c|c|}
\hline \multirow[t]{2}{*}{ Faktörler ve maddeler } & \multicolumn{2}{|c|}{$\begin{array}{l}\text { Açıklayıcı faktör } \\
\text { analizi }(n=430)\end{array}$} & \multicolumn{2}{|c|}{$\begin{array}{l}\text { Doğrulayıcı faktör } \\
\text { analizi } \\
(n=430)\end{array}$} \\
\hline & $\begin{array}{c}\text { Standardize } \\
\text { edilmiş } \\
\text { katsayı }\end{array}$ & $\mathbf{R}^{2}$ & $\begin{array}{c}\text { Standardize } \\
\text { edilmiş } \\
\text { katsayı }\end{array}$ & $\mathbf{R}^{2}$ \\
\hline \multicolumn{5}{|l|}{ Faktör 1: Öğrenme isteği } \\
\hline 5. Öğrenmeye açığımdır. & 0,71 & 0,59 & 0,61 & 0,44 \\
\hline 6. Dersle ilgili ödevlerde kendime güvenirim. & 0,67 & 0,64 & 0,81 & 0,81 \\
\hline \multicolumn{5}{|l|}{ Faktör 2: Öğrenme becerisi } \\
\hline 13. Hedeflerim gerçekçidir. & 0,56 & 0,50 & 0,64 & 0,57 \\
\hline $\begin{array}{l}\text { 15. Programdaki beklenmedik değişikliklere adapte } \\
\text { olabilir ve bu durumlara karşı tolerans gösterebilirim. }\end{array}$ & 0,58 & 0,51 & 0,52 & 0,38 \\
\hline 16. Görevlerimi öncelik sırasına göre düzenleyebilirim. & 0,69 & 0,45 & 0,71 & 0,65 \\
\hline $\begin{array}{l}\text { 17. Eksik olduğum ve daha bilgi edinmem gereken } \\
\text { konuların farkındayımdır. }\end{array}$ & 0,74 & 0,32 & 0,77 & 0,41 \\
\hline
\end{tabular}

\section{Faktör 3: Kültürel yeterlilik}

24. Diğer kişilerin kültürel farklılıklarına karşı saygı ve

0,77

0,33

0,67

0,27 anlayış gösteririm.

25. Farklı kişilerin duygu ve düşüncesine karşı

0,80

0,47

0,90

0,51 saygılıyımdır.

26. Diğer kişilerin sırlarına saygı gösteririm.

$0,70 \quad 0,54 \quad 0,75$

0,59

\begin{tabular}{lcc}
\hline Faktörler arası korelasyon & Tahmin & Tahmin \\
\hline F1, F2 & 0,58 & 0,71 \\
F1, F3 & 0,49 & 0,36 \\
F2, F3 & 0,46 & 0,47 \\
\hline Model Uyum Ölçütleri & & \\
\hline CFI & 0,98 & 0,96 \\
RMSEA & 0,05 & 0,06 \\
SRMR & 0,04 & 0,05
\end{tabular}

Mesleki Davranış Anketinin Türkçe Uyarlaması Ölçeğin Türkçe'ye uyarlama çalışmasının öncesinde ölçeği geliştiren araştırmacılardan e-mail aracılığı ile izin alındı. Dünya Sağlık Örgütü'nün ölçeklerin farklı dillere uyarlaması ile ilgili standart protokolü uygulandı (DSÖ, 2009).

1. Ölçeğin uyarlama yapılacak (hedef) dile çevrilmesi (Forward translation): Bu aşamada çevirmenin ilgili ölçeğin terminolojisini bilen sağlık uzmanı olması tercih edilmelidir. Çevirmen ölçeği hedef dile çevirir. Çalışmamızda ölçek hedef dile ilk iki yazar tarafından çevrildi.

2. Hedef dile çevrilen ölçeğin jüri tarafından görüşülmesi (Expert panel): Bu aşamada her iki dili bilen küçük bir jüri oluşturulmaktadır. Jüri üyeleri, ölçeği hedef dile çeviren sağlık uzmanı ve konu ile ilgili sağlık uzmanlarından oluşmalıdır. Bu aşamanın amacı; yetersiz ifade ve deyimleri belirlemek ve 
çözmektir. Bu aşamanın sonucunda hedef dile çevrilen ölçeğe son hali verilir. Çalışmamızda, jüri üyeleri oluşturuldu ve hedef dile çevrilen ölçeğe son hali verildi.

3. Ölçeğin hedef dilden orijinal dile çevrilmesi (Back translation): Bu aşamada önce çevirmen tarafından hedef dile çevrilen ve sağılı uzmanlarından oluşan jüride son hali verilen ölçek, ana dili ölçeğin dili olan ve konu ile hiçbir ilgisi olmayan çevirmen tarafından tekrar orijinal dile çevrilmektedir. Bu aşamada çevirinin kavramsal ve kültürel açıdan eşit olmasına dikkat edilmelidir. Bu aşamada ölçekler arasında farklılıklar olursa, önceki aşamalardan hangisi gerekli olursa tekrar edilir. Çalışmamızda her iki dili akıcı bir şekilde konuşabilen bir uzman tarafından ölçek hedef dilden orijinal dile (Ingilizce) çevrildi. Orijinal ölçek ile karşılaştırılarak diğer aşamaya geçildi.

4. Çevrilen ölçeğin test edilmesi ve kavramsal bütünlüğünün görüşülmesi: Ölçek ile ne ölçülmesi isteniyorsa belirlenen popülasyona uygulanır. $\mathrm{Bu}$ kişilere ölçekte anlamakta zorlandıkları ve karışık ifadelerin olup olmadığı sorulmalıdır. Eğer böyle ifadeler varsa bu kişilerin önerileri alınarak değiştirilmelidir. Mesleki Davranış Anketi, hedef popülasyonumuza uygun olarak 23 ergoterapi öğrencisine uygulanarak pilot çalışması yapıldı. Kişilere anlamakta zorlandıkları ve kafa karıştııcı maddelerin olup olmadığı soruldu. Ölçekten çıkarılması veya ölçeğe eklenmesi gereken ifadelerin bulunmadığı, soruların düzgün ve anlaşııı olduğu belirlenerek bir sonraki aşamaya geçildi.

5. Uyarlanmış ölçeğe son halinin verilmesi (Final version): Tüm aşamalarda değerlendirilen ölçeğin varsa düzeltmeleri yapılarak son hali verilmektedir. Yukarıdaki aşamaların sonunda, Mesleki Davranış Anketi'nin Türkçe versiyonuna son hali verildi.

\section{Istatistiksel Analiz}

İstatistiksel analizler IBM SPSS Statistics versiyon 23 ve IBM SPSS AMOS versiyon 23 programlariyla yapılmıştır. Verilerin normal dağılıma uygunluğu Shapiro-Wilk's testi ile incelenmiş ve verilerin normal dağılıma uygun olmadığı görülmüştür. Ölçeğin yapı geçerliliğini belirlemek üzere hem açıklayıcı faktör analizi hem de doğrulayıcı faktör analizi uygulanmıştır. Açıklayıcı faktör analizi için Kaiser Normalizasyon ile direkt oblimin eğik döndürme yöntemi kullanılan faktör analizi uygulanmış, maddeler faktör yükü 0,5 ve üzeri olan faktörlere dağıtılmıştır (Yaşlıoğlu, 2017). Doğrulayıcı faktör analizinde, modelin yapı geçerliliği model uyum ölçütlerinden ki-kare ile serbestlik derecesi oranı yoluyla model uyumu (x2/sd), hata kareler ortalamasının karekökü (RMR), karşılaştırmalı uyum indeksi (CFI), yaklaşık hataların ortalama karekökü (RMSEA), akaike bilgi kriteri (AIC) ve standartlaştırılmış hata kareler ortalamasının karekökü (SRMR) kullanılarak ortaya konulmuştur. Ki-kare ile serbestlik derecesi oranı yoluyla model uyumu için $0 \leq x 2 /$ sd $\leq 4$ mükemmel uyum, $4 \leq x 2 / s d \leq 5$ kabul edilebilir uyum; hata kareler ortalamasının karekökü için $<0,05$ mükemmel uyum, $0,05<R M R<0,08$ kabul edilebilir uyum; karşılaştırmalı uyum indeksi için $0,95 \leq \mathrm{CFI} \leq 1,00$ mükemmel uyum, $0,90 \leq C F \mid<0,95$ kabul edilebilir uyum; yaklaşık hataların ortalama karekökü için $0 \leq R M S E A \leq 0,05$ mükemmel uyum, $0,05<$ RMSEA $\leq 0,080$ kabul edilebilir uyum; standartlaştırılmış hata kareler ortalamasının karekökü için ise $0 \leq S R M R \leq 0,05$ mükemmel uyum, $0,05 \leq$ SRMR $\leq 0,10$ kabul edilebilir uyum göstergesi olarak kabul edilmiştir (Schermelleh-Engel, Moosbrugger ve Müller, 2003). Doğrulayıcı faktör analizi ile doğrulanan model altında madde-faktör korelasyon analizi yapılmış, iç tutarlıı̆ının incelenmesi için Cronbach alfa değeri hesaplanmıştır. Son olarak test-tekrar test korelasyonu değerlendirilmiştir. Tüm korelasyonlar için Spearman korelasyon analizi kullanılmıştır. Spearman korelasyon katsayısında $0,05-0,30$ arası düşük veya önemsiz korelasyon; $0,30-0,40$ arası düşük orta derecede korelasyon; $0,40-0,60$ arası orta derecede korelasyon; 0,60-0,70 arası iyi derecede korelasyon; $0,70-0,75$ arası çok iyi derecede korelasyon; 0,75-1 arası ise mükemmel korelasyon olarak kabul edilmiştir.

\section{SONUÇLAR}

Örneklem Yeterliliği ve Açıklayıcı Faktör Analizi

Keiser-Meyer-Olkin örneklem yeterliliği istatistiği $\mathrm{KMO}=0,809$ olarak hesaplanmış, örneklemin büyüklüğünün iyi olduğu saptanmıştır. Bartlett küresellik testi sonucuna göre maddeler arasında açıklayıcı faktör analizi yapmaya yeterli düzeyde ilişki olduğu saptanmıştır $(B=1557,55 ; p<0,01)$. Açıklayıcı faktör analizi sonuçlarına göre, MDA'nin toplam varyansın \%63,82'sinin yedi alt boyutta açıklanabileceği görülmüştür. Açıklayıcı faktör analizinde üç, beş, on bir ve on yedinci maddelerin faktör yük değerlerinin 0,50'nin altında kaldığı görülmüş ve bu dört madde çıkartılarak açıklayıcı faktör analizi tekrarlanmıştır. Tekrarlanan açıklayıcı faktör analizi sonucunda ise altıncı maddenin de faktör yük değerinin 0,50'nin altında kaldığı görülmüş ve bu madde de çıkartılmıştır (Balcı, 2018). Üçüncü açıklayıcı faktör analizi sonucunda, rotasyon yöntemi 
olarak direkt oblimin eğik döndürme yöntemi kullanıldığında 23 madde yedi faktöre Tablo 2'deki gibi bir yapı ile katkı sağlamaktadır. Tablo 2 incelendiğinde, birinci faktörün (öz-yeterlilik) 12, 13, 14, 21, 22 ve 23; ikinci faktörün (sağduyulu olma) 7, 24, 25 ve 26; üçüncü faktörün (öğrenme isteği) 1 ve 2; dördüncü faktörün (eleştirel olma) 18, 19 ve 20, beşinci faktörün (mesleki sorumluluk) 27 ve 28; altıncı faktörün (iletişim becerisi) 9 ve 10 madde; yedinci faktörün (inisiyatif kullanabilme) ise 4, 8, 15 ve 16. maddelerden oluştuğu görülmektedir. Tablo 2'de görüldüğü üzere sağduyulu olma faktöründe yer alan 7, 24, 25 ve 26. maddeler; eleştirel olma faktöründe yer alan 18, 19 ve 20. maddeler ve inisiyatif kullanabilme faktöründe yer alan 4, 8, 15 ve 16. maddeler ters kodlanmaktadır.

Doğrulayıcı Faktör Analizi (DFA)

Açıklayıcı faktör analizi sonucunda Türkçe uyarlaması yapılan Mesleki Davranış Anketi'nin orijinal ölçekteki faktör yapısından ayrıştığı anlaşılmıştır. Bu nedenle ölçek orijinal faktör yapısına bakmaksızın değerlendirilmiş ve Şekil 1 ile verilen yapıda doğrulayıcı faktör analizi kullanılarak test edilmiştir (Şekil 1).

Tablo 2. Ortak yükler ve açıklayıcı faktör analizi

\begin{tabular}{|c|c|c|c|c|c|c|c|c|}
\hline \multirow{2}{*}{$\begin{array}{l}\text { MDA } \\
\text { madde }\end{array}$} & \multirow{2}{*}{$\begin{array}{l}\text { Ortak } \\
\text { yükler }\end{array}$} & \multicolumn{7}{|c|}{ Faktör yapısı ve faktör yükleri } \\
\hline & & $\begin{array}{l}\text { Öz- } \\
\text { yeterlilik }\end{array}$ & $\begin{array}{l}\text { Sağduyulu } \\
\text { olma }\end{array}$ & $\begin{array}{l}\text { Öğrenme } \\
\text { isteği }\end{array}$ & $\begin{array}{l}\text { Eleştirel } \\
\text { olma }\end{array}$ & $\begin{array}{l}\text { Mesleki } \\
\text { sorumluluk }\end{array}$ & $\begin{array}{l}\text { İletişim } \\
\text { becerisi }\end{array}$ & $\begin{array}{l}\text { Inisiyatif } \\
\text { kullanabilme }\end{array}$ \\
\hline 1 & 0,732 & & & 0,808 & & & & \\
\hline 2 & 0,744 & & & 0,864 & & & & \\
\hline $4^{*}$ & 0,637 & & & & & & & $-0,541$ \\
\hline $7^{*}$ & 0,659 & & $-0,584$ & & & & & \\
\hline $8^{*}$ & 0,593 & & & & & & & $-0,623$ \\
\hline 9 & 0,739 & & & & & & 0,831 & \\
\hline 10 & 0,660 & & & & & & 0,756 & \\
\hline 12 & 0,580 & 0,689 & & & & & & \\
\hline 13 & 0,585 & 0,620 & & & & & & \\
\hline 14 & 0,495 & 0,634 & & & & & & \\
\hline $15^{*}$ & 0,685 & & & & & & & $-0,738$ \\
\hline $16^{*}$ & 0,654 & & & & & & & $-0,601$ \\
\hline $18^{*}$ & 0,562 & & & & $-0,580$ & & & \\
\hline $19^{*}$ & 0,558 & & & & $-0,638$ & & & \\
\hline $20^{*}$ & 0,597 & & & & $-0,646$ & & & \\
\hline 21 & 0,577 & 0,613 & & & & & & \\
\hline 22 & 0,674 & 0,601 & & & & & & \\
\hline 23 & 0,549 & 0,628 & & & & & & \\
\hline $24^{*}$ & 0,735 & & $-0,860$ & & & & & \\
\hline $25^{*}$ & 0,735 & & $-0,823$ & & & & & \\
\hline $26^{*}$ & 0,701 & & $-0,752$ & & & & & \\
\hline 27 & 0,583 & & & & & 0,651 & & \\
\hline 28 & 0,644 & & & & & 0,737 & & \\
\hline
\end{tabular}

Temel bileşenler analizi döndürme yöntemi: Kaiser normalizasyon ile direkt oblimin eğik döndürme yöntemi; MDA: Mesleki Davranış Anketi; *Ters kodlanan maddeler

Modelin en iyi uyumu öz yeterlilik alt ölçeğinde yer alan 22. maddenin madde hataları ile, 12. ( $r=-0,07)$, 13. $(r=-0,06)$ ve 21. $(r=0,04)$ maddelerinin madde hatalarının; sağduyulu olma alt ölçeğinde ise 7 . ve
26. maddelerin madde hatalarının $(r=0,05)$ korele edilmesiyle bulunmuştur. Buna göre model uyum ölçüleri, $\quad X 2(100)=276,73, \quad p=0,001, \quad X 2 / s d=1,350$, $\mathrm{RMR}=0,034, \mathrm{CFI}=0,926 ; \mathrm{RMSEA}=0,04, \mathrm{AIC}=418,6$ 
ve SRMR= 0,066 olarak elde edilmiş ve bu modelin uyumunun iyi düzeyde olduğu saptanmıştır.

Cronbach Alfa

Tablo 3'te ölçeğin tamamına ilişkin madde-toplam istatistikleri verilmiştir. Tablo 3'te görüldüğü üzere hiçbir madde, silindiği takdirde ölçeğin Cronbach alfa değerinde anlamlı bir artış meydana gelmemektedir. Bu nedenle Cronbach alfa değeri nedeniyle herhangi bir madde silinmemiştir. Güvenilirlik analizlerinden ölçeğin iç tutarlılığını gösteren Cronbach alfa katsayısı $\alpha=0,858$ olarak hesaplanmıştır. Her bir alt ölçeğin Cronbach alfa değerleri sırasıyla; öz-yeterlilik için 0,788; sağduyulu olma için 0,796 ; öğrenme isteği için 0,649; eleştirel olma için 0,681, mesleki sorumluluk için 0,472 ; iletişim becerisi için 0,662 ; inisiyatif kullanabilme 0,690 olarak hesaplanmıştır.
Ergoterapi öğrencileri arasından rastgele seçilen, ulaşılabilen ve testi tekrar uygulamayı kabul eden 23 öğrenciye ölçeği ilk doldurdukları tarihten 4 hafta sonra test tekrar uygulanmıştır. Test-tekrar test güvenilirliğini değerlendirmek için başlangıç değerleriyle tekrar-test değerleri Spearman korelasyon analizi uygulanarak karşılaştırılmıştır. MDA'nın alt ölçeklerinden öz-yeterlilik ve sağduyulu olma alt ölçeklerinin tekrar testleriyle anlamlı korelasyonu olduğu (sırasıyla $r=0,761 ; p=0,02$; $r=0,783 ; p<0,01)$ saptanmıştır. Ancak öğrenme isteği, eleştirel olma, mesleki sorumluluk, iletişim becerisi ve inisiyatif kullanabilme alt ölçeklerinin tekrar testleriyle korelasyonu anlamlı bulunmamıştır (sırasıyla $r=0,178 ; p=0,40 ; r=0,365 ; p=0,07$ ). Test-Tekrar Test Güvenilirliği

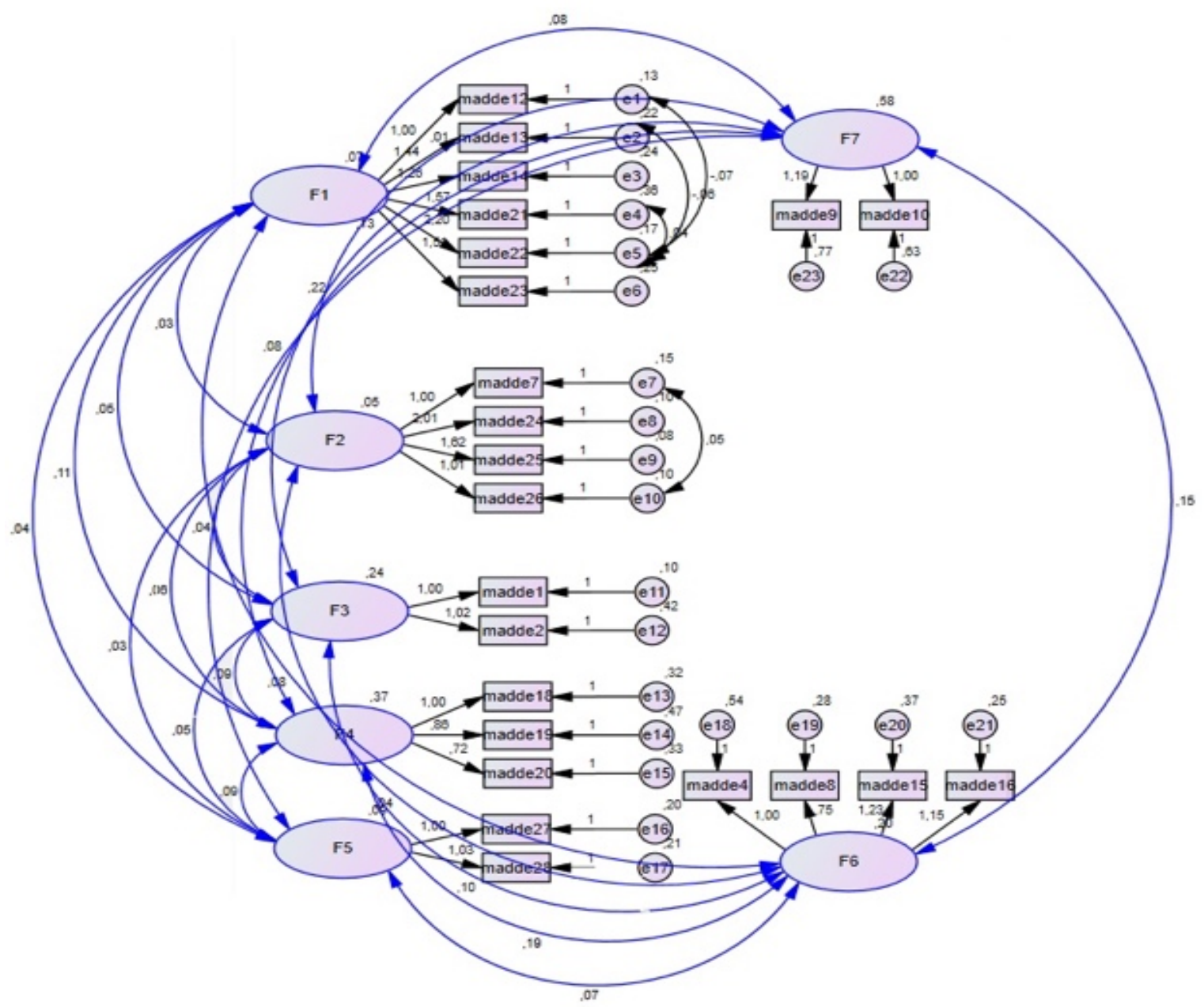

Şekil 1. Doğrulayıcı faktör analizinde test edilen 23 maddenin yer aldığı 7 faktörlü yapı; model uyum ölçüleri: $X 2(100)=276,73, p=0,001, X 2 / s d=1,350, R M R=0,034, C F I=0,926 ; R M S E A=0,04, A I C=418,6, S R M R=0,066 ; F 1$, öz-yeterlilik; F2, sağduyulu olma; F3, öğrenme isteği; F4, eleştirel olma; F5, mesleki sorumluluk; F6, inisiyatif kullanabilme; $F 7$, iletişim becerisi 
Tablo 3. Ölçeğin tamamına ilişkin madde-toplam istatistikleri

\begin{tabular}{|c|c|c|c|c|}
\hline $\begin{array}{c}\text { MDA } \\
\text { maddeleri }\end{array}$ & $\begin{array}{l}\text { Madde silindiğinde } \\
\text { ölçeğin ortalaması }\end{array}$ & $\begin{array}{l}\text { Madde silindiğinde } \\
\text { ölçeğin varyansı }\end{array}$ & $\begin{array}{l}\text { Düzeltilmiş madde } \\
\text { toplam korelasyonu }\end{array}$ & $\begin{array}{c}\text { Madde silindiğinde } \\
\text { Cronbach alfa }\end{array}$ \\
\hline 1 & 111,3510 & 92,309 & 0,455 & 0,884 \\
\hline 2 & 111,9139 & 91,746 & 0,337 & 0,887 \\
\hline $3^{*}$ & 111,3046 & 93,213 & 0,324 & 0,887 \\
\hline 4 & 112,2450 & 89,546 & 0,456 & 0,884 \\
\hline $5^{*}$ & 111,0265 & 92,786 & 0,439 & 0,885 \\
\hline $6^{* *}$ & 111,3444 & 89,334 & 0,598 & 0,881 \\
\hline 7 & 110,7947 & 93,964 & 0,403 & 0,886 \\
\hline 8 & 111,2517 & 91,710 & 0,467 & 0,884 \\
\hline 9 & 112,7947 & 87,511 & 0,363 & 0,891 \\
\hline 10 & 112,7020 & 88,944 & 0,362 & 0,889 \\
\hline $11^{*}$ & 111,3974 & 90,094 & 0,610 & 0,881 \\
\hline 12 & 110,8609 & 93,841 & 0,424 & 0,885 \\
\hline 13 & 111,2980 & 91,451 & 0,502 & 0,883 \\
\hline 14 & 111,1722 & 92,237 & 0,444 & 0,884 \\
\hline 15 & 111,7351 & 89,476 & 0,487 & 0,883 \\
\hline 16 & 111,4172 & 89,658 & 0,558 & 0,882 \\
\hline $17^{*}$ & 111,3444 & 90,627 & 0,621 & 0,881 \\
\hline 18 & 111,8808 & 88,519 & 0,539 & 0,882 \\
\hline 19 & 111,9470 & 89,371 & 0,464 & 0,884 \\
\hline 20 & 111,6623 & 90,545 & 0,483 & 0,883 \\
\hline 21 & 111,4636 & 90,557 & 0,472 & 0,884 \\
\hline 22 & 111,7616 & 88,569 & 0,627 & 0,880 \\
\hline 23 & 111,3974 & 90,174 & 0,581 & 0,882 \\
\hline 24 & 110,9470 & 92,957 & 0,404 & 0,885 \\
\hline 25 & 110,9205 & 93,620 & 0,424 & 0,885 \\
\hline 26 & 110,7682 & 94,886 & 0,355 & 0,886 \\
\hline 27 & 110,9007 & 93,850 & 0,348 & 0,886 \\
\hline 28 & 111,1325 & 93,742 & 0,347 & 0,886 \\
\hline
\end{tabular}

* İlk açıklayıcı faktör analizi sonucunda faktör yük değeri 0,50'nin altına kalan maddeler; ** ikinci açıklayıcı faktör analizi sonucunda faktör yük değeri 0,50'nin altına kalan madde

\section{TARTIŞMA}

$\mathrm{Bu}$ çalışmada ergoterapi öğrencilerinin mesleki davranışlarını değerlendiren bir ölçek olan Mesleki Davranış Anketi'nin Türkçeye çevrilerek geçerlilik ve güvenilirlik çalışmasının yapılması amaçlanmıştır. Açıklayıcı faktör analizi ile ölçeğin özgün formuna benzer olmayan şekilde yedi faktörlü model elde edilmiş ve alt ölçekler "öz-yeterlilik", "sağduyulu olma”, "öğrenme isteği”, "eleştirel olma”, "mesleki sorumluluk", "iletişim becerisi" ve "inisiyatif kullanabilme" olarak adlandırılmıştır. Ölçeğin maddelerinin faktörlere dağılımı orijinal ölçekten farklılık göstermiş; üç, beş, altı, on bir ve on yedinci maddelerin hiçbir faktöre katkı sağlamaması nedeniyle bu maddeler ölçekten çıkarılarak doğrulayıcı faktör analizi yapılmıştır. Bu modelin uyumunun iyi düzeyde olduğu görülmüştür. Ölçeğin iç tutarlılığı ve test-tekrar test güvenilirliği incelenmiştir. Türkçe formunun geçerlilik ve güvenilirlik açısından kabul edilebilir sınırlarda olduğu görülmüştür.

İç tutarlılığının değerlendirildiği Cronbach alfa testi sonuçlarında MDA Cronbach alfa katsayısı 0,858 olup ölçeğin özgün formunun Cronbach alfa 
$(0,79)$ katsayı değerinden yüksektir. Bu değer güvenilirlik testleriyle ilgili sınıflamada orta-yüksek düzeyde güvenilir olarak kabul edilmektedir (Özdamar, 1999). Alt ölçeklerin Cronbach alfa değerleri; öz-yeterlilik için 0,788; sağduyulu olma için 0,796 ; öğrenme isteği için 0,649 ; eleştirel olma için 0,681 , mesleki sorumluluk için 0,472; iletişim becerisi için 0,662 ; inisiyatif kullanabilme 0,690 olarak hesaplanmıştır. Özdamar (1999)'ın önerdiği sınıflamaya göre; öz-yeterlilik, sağduyulu olma, öğrenme isteği, eleştirel olma, iletişim becerisi ve inisiyatif kullanabilme alt ölçekleri orta düzeyde, mesleki sorumluluk alt ölçeği ise düşük düzeyde güvenilir olarak değerlendirilmektedir. Ölçeğin özgün formunda ise öğrenme isteği, öğrenme becerisi ve kültürel yeterlilik alt ölçeklerinin Cronbach alfa değerleri sırasıyla 0,63,0,72 ve 0,79'dur. Ölçeğin farklı psikometrik özellikler göstermesinin kültürel özelliklerden kaynaklanabileceği düşünülmektedir.

Mesleki Davranış Anketi ergoterapi öğrencileri için mesleki davranışı ölçen bir değerlendirme aracıdır. Türkçede var olan ve ergoterapi öğrencilerine veya ergoterapistlere yönelik mesleki davranışları değerlendiren başka bir araç bulunmadığı için Mesleki Davranış Anketi'nin dış geçerliliğinin değerlendirilmesinde böyle bir ölçek kullanılamadı, bu çalışmanın bir kısıtııı̆ıdır. Ayrıca, diğer bir kısıtlılık örneklemin çoğunlukla kız öğrenciler oluşması nedeniyle ölçeğin cinsiyet gibi demografik bilgilerle korelasyonuna bakılamamasıdır. Bir başka kısıtlılık ise faktör analizi sırasında beş maddenin bir faktörde faktörleşmemesi nedeniyle Türkçe ölçekten çıkarılmasıdır. Bu maddelerin farklı davranması Türkçeye çeviride anlamını kaybetmiş olması ile ilgili olabileceği gibi Türkiye örnekleminin kültürel özellikleriyle de ilgili olabilir. Daha ileri çalışmalarda ölçekte dilimize uygun başka değişiklikler yapılarak analizlerin tekrarlanması önerilir.

Ergoterapi öğrencilerinde mesleki davranışlarının belirlenmesinin ergoterapi mesleğinin gelişimi açısından önemli olacağını düşünmekteyiz. Ergoterapi öğrencilerinin mesleki davranışlarını belirleyen Mesleki Davranış Anketi'nin Türkçe formu geçerli ve güvenilir bir ölçektir.

Araştırmacıların Katkı Oranı

Fikir/Kavram: Gonca Bumin; Tasarım: Gökçen Akyürek, Gonca Bumin; Denetleme/ Danışmanlık: Gökçen Akyürek; Veri Toplama ve/veya İşleme: Sinem Kars; Analiz ve/veya Yorum: Sinem Kars; Kaynak Taraması: Sinem Kars; Makalenin Yazımı: Sinem Kars, Gökçen Akyürek; Eleştirel İnceleme: Sinem Kars, Gökçen Akyürek

\section{Çıkar Çatışması Beyanı}

Yazarlar arasında çıkar çatışması bulunmamaktadır. Destek/ Teşekkür

Çalışma sırasında hiçbir kurum ya da kişiden finansal destek alınmamıştır. Çalışmaya katılmayı gönüllü olarak kabul eden ve destekleyen katılımcılara tüm yazarlar teşekkür eder.

\section{Kaynaklar}

Bazı Kanun Ve Kanun Hükmünde Kararnamelerde Değişiklik Yapılmasına Dair Kanun (2011, 26 Nisan). Resmi Gazete (Sayı: 27916 (Mükerrer). Erişim adresi: https://www.resmigazete.gov.tr/eskiler/2011/04/2011042 6-1.htm

Balcı, A. (2018). Sosyal Bilimlerde Araştırma Yöntem Teknik ve Ilkeler (13. Baskı). Ankara: Pegem Akademi.

Brown, T., Williams, B., \& Etherington, J. (2016). Emotional intelligence and personality traits as predictors of occupational therapy students' practice education performance: A cross-sectional study. Occup Ther Int, 23(4), 412-424. https://doi.org/10.1002/oti.1443

Çelik, S., Ünal, Ü., \& Saruhan, S. (2012). Cerrahi kliniklerde çalışan hemşirelerin mesleki profesyonelliklerinin değerlendirilmesi. Florence Nightingale Hemşirelik Dergisi, 20(3), 193-199.

Dünya Sağlık Örgütü. (2009). Process of translation and adaptation of instruments. Retrieved from the Web September $12,2019$. https://www.who.int/substance_abuse/research_tools/tra nslation/en/

Flexner, A. (2001). Is social work a profession? Res Soc Work Pract, 11(2), 152-165. https://doi.org/10.1177/104973150101100202

Güven, T. (2009). Tıp etiği açısından meslek ve profesyonellik kavramlarının incelenmesi. Hacettepe Tıp Dergisi, 40(2), 84-88.

Hackenberg, G. R., \& Toth-Cohen, S. (2018). Professional behaviors and fieldwork: A curriculum based model in occupational therapy. Journal of Occupational Therapy Education, 2(2), 1-6. https://doi.org/10.26681/jote.2018.020203

Özdamar, K. (1999). Paket Programlar ile Istatistiksel Veri Analizi 1. Eskişehir: Kaan Kitabevi.

Schermelleh-Engel, K., Moosbrugger, H., \& Müller, H. (2003). Evaluating the fit of structural equation models: Tests of significance and descriptive goodness-of-fit measures. Methods of Psychological Research Online, 8(2), 23-74.

Sullivan, T. M., \& Thiessen, A. K. (2015). Occupational therapy students' perspectives of professionalism: An exploratory study. The Open Journal of Occupational Therapy, 3(4), 1-17. https://doi.org/10.15453/2168-6408.1154

Yaşlıoğlu, M. M. (2017). Sosyal bilimlerde faktör analizi ve geçerlilik: Keşfedici ve doğrulayıcı faktör analizlerinin kullanılması. Istanbul Üniversitesi Işletme Fakültesi Dergisi, 46(Özel sayı), 74-85.

Yuen, H. K., Azuero, A., Lackey, K. W., Brown, N. S., \& Shrestha, S. (2016). Construct validity test of evaluation tool for professional behaviors of entry-level occupational therapy students in the United States. J Educ Eval Health Prof, 13, 22-27. https://doi.org/10.3352/jeehp.2016.13.22 